\title{
Incidence and prevalence of diabetes self-reported on elderly in south of Brazil: results of EpiFloripa Ageing Study
}

\author{
Incidência e prevalência de diabetes autorreferido em idosos do sul \\ do Brasil: resultados do estudo EpiFloripa Idoso
}

Carla Elane Silva dos Santos (http://orcid.org/0000-0002-3659-6921) ${ }^{1}$

Cassiano Ricardo Rech (http://orcid.org/0000-0002-9647-3448) ${ }^{1}$

Danielle Ledur Antes (http://orcid.org/0000-0002-9611-519X) ${ }^{2}$

Ione Jayce Ceolla Schneider (http://orcid.org/0000-0001-6339-7832) ${ }^{2}$

Eleonora d'Orsi (https://orcid.org/0000-0003-2027-1089) ${ }^{2}$

Tânia Rosane Bertoldo Benedetti (http://orcid.org/0000-0002-2035-5082) ${ }^{1}$
${ }^{1}$ Departamento de

Educação Física, Centro de Desportos, Universidade

Federal de Santa Catarina (UFSC). Campus Universitário, Trindade. 88010-970 Florianópolis SC Brasil.

carlaef_uesb@hotmail.com

${ }^{2}$ Departamento de

Saúde Pública, UFSC.

Florianópolis SC Brasil.

\begin{abstract}
This study investigated the prevalen$c e$ and incidence of diabetes self-referred in the elderly. Longitudinal population-based study (EpiFloripa Ageing Study), with 1.702 elderly in 2009/10 and 1.197 in 2013/14 of Florianópolis, SC. Self-reported and anthropometric data were collected at home. The prevalence of diabetes self-referred in 2009/10 was $22.1 \%$ (95\%CI 20.1-24.1). The characteristics were: no formal schooling (2.30; CI95\% 1.32-4.00); 5 to 8 years of schooling (OR = 1.70, CI95\% 1.07-2.69); increased waist circumference $(O R=3.31$, CI95\% 2.05-5.34) and hypertension $(O R=2.38, C I 95 \%$ : 1.68-3.36). The incidence of diabetes self-reported after four years of follow-up was 8.3\% (95\% CI, 6.7-10.3). After adjustment: increased waist circumference (OR=2.23, CI95\% 1.09-4.57) at baseline was associated with the incidence of diabetes. The prevalence and incidence of diabetes were high among the elderly. Interventions must be performed especially with elderly with low and without formal schooling, with increased waist circumference and hypertension, thus they were the subgroups with higher odds ratio of reporting and developing diabetes.
\end{abstract}

Key words Elderly, Diabetes, Prevalence, Incidence, Risk factors
Resumo Este estudo investigou a prevalência e $a$ incidência de diabetes autorreferido em idosos. Estudo longitudinal de base populacional (Estudo EpiFloripa Idoso), com 1.702 idosos em 2009/10 e 1197 em 2013/14, de Florianópolis, SC. Os dados autorrelatados e antropométricos foram coletados no domicílio. A prevalência de diabetes em 2009/10 foi de 22,1\% (IC 95\%: 20,1-24,1). As características associadas com a prevalência de diabetes foram: não possuir escolaridade formal $(\mathrm{OR}=2,30$; IC95\% 1,32-4,00); ter 5 a 8 anos de estudo (OR = 1,70, IC95\% 1,07-2,69); circunferência da cintura aumentada $(O R=3,31$, IC95\% 2,05-5,34) e hipertensão (OR $=2,38$, IC95\%: 1,68-3,36). A incidência de diabetes autorreferida após quatro anos de acompanhamento foi de 8,3\% (IC95\% 6,7-10,3), e apresentar circunferência da cintura aumentada $(O R=2,23$, IC95\% 1,09-4,57) na linha de base foi associado à incidência de diabetes. A prevalência e incidência de diabetes foram elevadas entre os idosos. Intervenções devem ser realizadas especialmente com idosos de baixa ou sem escolaridade formal, com maior circunferência da cintura e hipertensão, pois foram os subgrupos com maiores chances de relatar e desenvolver diabetes.

Palavras-chave Idoso, Diabetes, Prevalência, Incidência, Fatores de risco 


\section{Introduction}

Diabetes is considered a public health problem and treated as a priority by the World Health Organization $^{1}$. At the global level, it is estimated that 382 million people were affected by the disease in the year 2013, and with projections for 592 million new cases by the year $2035^{2}$, especially in the most advanced age groups ${ }^{3}$. Evidences show a $25 \%$ increasing in the prevalence of diabetes among adults from 2006 to $2014^{4}$. Especially among the elderly, the prevalence of $24.4 \%$ was only reached in 2014 , signaling great concern for the national health scenario ${ }^{4}$.

The high number of diabetes cases in the population and the time of exposure to hyperglycemia requires attention of health care professionals and managers. The disease favors the onset of acute and chronic problems ${ }^{5}$, increased rates of hospitalizations ${ }^{6}$, premature disability and mortality ${ }^{7}$. In addition to economic and social damages ${ }^{8,9}$. In contrast, public policies can help to preserve the health of the elderly by means of preventive measures such as health education ${ }^{5}$.

Thus multiple risk factors and characteristics may be associated with diabetes, such as population growth and aging, increased urbanization $^{5}$, family history ${ }^{10}$, aged 60 to $75^{11}$, female gender $^{12}$, hypertension ${ }^{13,14}$, inadequate food consumption $^{15}$, obesity ${ }^{16}$, low schooling ${ }^{17,18}$, low socioeconomic status ${ }^{11}$ and low levels of physical activity ${ }^{19}$. Most of the studies cited above are presented cross-sectional, and do not allow us to understand over time the factors that contributed to the development of the disease. In Brazil, a longitudinal study was conducted in the southeastern region of the country, and showed that abdominal fat was considered a risk factor for the incidence of diabetes in the six-year period ${ }^{20}$.

Thus, the objective of this study was to identify the factors associated to the prevalence and incidence of diabetes self-reported in the elderly of a capital in the South of Brazil.

\section{Methods}

This population-based cohort study analyzed data from the EpiFloripa Ageing Study that aims to know the life and health conditions of the elderly population living in Florianópolis $(\geq 60$ years). The first wave occurred in 2009/10 and the second in 2013/14. The study was conducted in Florianópolis, capital of the state of Santa Ca- tarina and has a high Human Development Index of (0.847), being higher than Brazil average $(0.755)^{21}$.

The population was constituted by elderly $(\geq$ 60 years) of both genders, living in Florianópolis. The selection process for the sample was in two stages of clusters. In the first stage, 80 of the 420 urban census tracts were systematically selected according to the average monthly income of the head of the household (eight sectors in each income decile). In the second stage, the units were the households. The sectors with less than 150 households were grouped and those with more than 500 households (respecting the corresponding decile of income) were divided, originating 83 census tracts.

The parameters adopted for performing the first wave sample were: total population of 44.460 older adults, unknowing outcome (50\%), sampling error equal to four percentage points, design effect equal to two, and 95\% confidence interval (95\% CI). The rate of $20 \%$ for losses and $15 \%$ for association study control were added, which resulted in a minimum desirable sample of 1,599 individuals.

Exclusion criteria was the institutionalized elderly (long-term care institution, prisons and hospitals). As losses were considered those that were not located after four attempts in different shifts and weekends. Of the eligible elderly residents $(\mathrm{n}=1,911), 1,705$ were interviewed, and the response rate was $89.2 \%$.

To carry out the following-up (2013/2014), attempts were made to contact and interview all the participants who changed their city, within the metropolitan region of Florianópolis. Those who could not be interviewed were considered as losses, and those who did not want to participate in the second wave and who were unable to respond for reasons of being traveling were considered as refusals.

A total of 220 participants were excluded, 217 due to deaths, 2 due to having duplicate data and one being incompatible with the study in the year $2009 / 10$. A total 1,485 elderly were eligible for follow-up. However 129 elderly people refused to participate in the second wave and 159 were considered losses; from these, 111 for non-located, which resulted 1,197 interviews, achieving a response rate of $70.3 \%$.

The EpiFloripa Ageing Study in the baseline was approved by the Research Ethics Committee of the Federal University of Santa Catarina, and the second wave under CAAE. All study participants signed the Informed Consent Term. 


\section{Dependent variable}

The outcome of the present study was self-reported diabetes, based on the question: "Has any doctor or health professional ever told you that you have/had diabetes?" As alternatives answers: yes or no. This question was included both at baseline and following-up.

\section{Independent variables}

The independent variables were: gender (female and male), aged (60-69, $70-79,80$ years or more), marital status (married/with partner, single, divorced/separated, widowed); schooling (no formal schooling, 1-4, 5-8, 9-11, $\geq 12$ years), physical activity of leisure time ${ }^{22}$ (active and insufficiently active), exchange messages over the internet (yes, no), waist circumference (normal, increased [increased + greatly increased] $)^{23}$, and self-referred morbidities such as hypertension, stroke, chronic kidney failure, depression, cardiovascular disease. Answers may be positive or negative.

\section{Statistical analysis}

In both analyzes descriptive statistics (absolute frequency and proportion) were used according to the nature of the exposures. The prevalence in 2009/10 and the incidence self-reported of the outcome between 2009/10 and 2013/14 were calculated. The incidence was obtained by dividing the number of new cases identified in the following-up period (average of four years) by the number of participants without the disease in the baseline. For the crude and adjusted analyzes, the logistic regression was applied to estimative the odds ratio and their respective 95\% confidence intervals.

The first variables tested in the adjusted analysis were sociodemographic variables (gender, age group, marital status and schooling), followed by behavioral (physical activity and exchange of messages over the internet) and health variables (waist circumference, hypertension, stroke, chronic kidney failure, depression, cardiovascular disease). Were included in the adjusted analysis all the variables of the crude analysis independent of the $\mathrm{p}$-value.

Data analysis was performed using Stata 13.0 (Stata Corporation, College Station, USA), considering the effect of the sampling design by clusters and incorporating the sampling weights. The level of statistical significance adopted in all analyzes was $\mathrm{p}$-value $\mathrm{p} \leq 0.05$.

\section{Results}

A total of 1.702 elderly performed at baseline (Table 1) and 1.197 at following up (Table 2). There was a higher proportion of women, elderly with aged 60 to 69 years, married subjects, those with low educational level, those insufficiently active at leisure, who did not exchange messages by internet, those with increased waist circumference and those with hypertension.

The prevalence of diabetes self-reported (22.1\%; CI95\%; 20.1-24.1) was higher among elderly without formal schooling, those who did not exchange messages over the internet, those with increased waist circumference, and in those who reported hypertension, cardiovascular disease, stroke, chronic kidney failure and depression (Table 1). After adjustments the characteristics associated with the prevalence of diabetes were: no formal schooling $(\mathrm{OR}=2.30,95 \% \mathrm{CI}$ 1.32-4.00), 5 to 8 years of schooling $(\mathrm{OR}=1.70$; 95\% CI 1.07-2.69), increased abdominal circumference $(\mathrm{OR}=3.31 ; 95 \% \mathrm{CI} 2.05-5.34)$, and hypertension $(\mathrm{OR}=2.38$; 95\% CI 1.68-3.36) (Table $1)$.

After an average of four years of follow-up, the incidence was of the $8.3 \%$ (95\% CI: 6.7-10.3), and increased odds of developing diabetes were identified in crude analysis for the elderly with increased waist circumference and depression (at the baseline) (2009/10) (Table 2). After adjusting for the final model, those who had increased waist circumference at baseline ( $\mathrm{OR}=2.23 ; 95 \%$ CI: 1.09-4.57), increased their odds of developing diabetes after four years (Table 2).

\section{Discussion}

The results of the present study showed a high prevalence of diabetes self-reported $22.1 \%$ (CI95\% 20.1-24.1), and this was associated with subjects no formal schooling or low schooling, increased values of waist circumference and and diagnosis of hypertension. It also indicated an incidence of $8.3 \%$ (95\% CI 6.7-10.3), after four years of following-up, associated to subgroups those who had increased waist circumference at baseline.

The prevalence of diabetes self-reported found resembled national studies ${ }^{24,25}$ and international ${ }^{26,27}$ and was higher than the prevalence found in the municipality of Florianopolis in the year 2002, which was $13.5 \%$ among the elderly ${ }^{28}$. The increased prevalence of diabetes over the years throughout the world may be associated to 
Table 1. Characteristics of baseline participants and association of diabetes prevalence self-reported in the elderly. Florianopolis, Brazil, 2009/10.

\begin{tabular}{|c|c|c|c|c|c|c|}
\hline Variables & $\mathbf{n}^{\star}(\%)$ & $\begin{array}{c}\text { Prevalence of } \\
\text { Diabetes } \\
(95 \text { CI\%) }\end{array}$ & $\begin{array}{l}\text { OR Crude (95 } \\
\text { CI\%) }\end{array}$ & p value & $\begin{array}{l}\text { OR Adjusted } \\
\quad(95 \mathrm{CI} \%)\end{array}$ & p value \\
\hline Gender & & & & 0.170 & & 0.151 \\
\hline Male & $614(36.1)$ & $20.6(17.0-24.8)$ & 1.00 & & 1.00 & \\
\hline Female & $1,088(63.9)$ & $27.6(24.5-30.8)$ & $1.19(0.93-1.51)$ & & $1.30(0.94-1.82)$ & \\
\hline Age Group (years) & & & & 0.051 & & 0.065 \\
\hline $60-69$ & $841(49.6)$ & $18.7(16.2-21.4)$ & 1.00 & & 1.00 & \\
\hline $70-79$ & $615(36.2)$ & $26.8(23.5-30.5)$ & $1.60(1.24-2.05)$ & & $1.56(1.15-2.12)$ & \\
\hline$\geq 80$ & $239(14.1)$ & $20.5(15.8-26.1)$ & $1.12(0.79-1.61)$ & & $1.18(0.71-1.95)$ & \\
\hline Marital status & & & & 0.790 & & 0.590 \\
\hline Married & $990(58.1)$ & $22.3(19.8-25.0)$ & 1.00 & & 1.00 & \\
\hline Single & $99(5.9)$ & $15.1(09.3-23.7)$ & $0.62(0.35-1.10)$ & & $0.51(0.25-1.04)$ & \\
\hline Divorced/separated & $132(7.8)$ & $21.2(15.0-29.0)$ & $0.94(0.60-1.50)$ & & $1.10(0.63-1.91)$ & \\
\hline Widow & $481(28.2)$ & $23.1(19.5-27.1)$ & $1.05(0.81-1.36)$ & & $0.87(0.61-1.25)$ & \\
\hline Schooling (years) & & & & 0.002 & & 0.005 \\
\hline$\geq 12$ & $295(24.6)$ & $16.3(12.5-20.9)$ & 1.00 & & 1.00 & \\
\hline $9-11$ & $180(15.1)$ & $19.4(14.3-25.9)$ & $1.24(0.77-2.01)$ & & $1.22(0.75-2.01)$ & \\
\hline $5-8$ & $199(16.6)$ & $25.1(19.6-31.6)$ & $1.73(1.11-2.70)$ & & $1.70(1.07-2.69)$ & \\
\hline $1-4$ & $430(35.9)$ & $22.8(19.1-27.0)$ & $1.52(1.04-2.23)$ & & $1.43(0.95-2.13)$ & \\
\hline No formal schooling & $93(7.8)$ & $31.2(22.6-41.3)$ & $2.33(1.37-3.99)$ & & $2.30(1.32-4.00)$ & \\
\hline Physical activity of leisure & & & & 0.075 & & 0.245 \\
\hline \multicolumn{7}{|l|}{ Time } \\
\hline Active & $494(29.1)$ & $19.2(16.0-23.0)$ & 1.00 & & 1.00 & \\
\hline Insufficiently active & $1,208(70.9)$ & $23.2(20.9-25.6)$ & $1.27(0.97-1.65)$ & & $1.20(0.87-1.66)$ & \\
\hline $\begin{array}{l}\text { Exchange messages over } \\
\text { the internet }\end{array}$ & & & & 0.003 & & 0.318 \\
\hline Yes & $344(20.2)$ & $16.0(12.4-20.3)$ & 1.00 & & 1.00 & \\
\hline No & $1,358(79.8)$ & $23.6(21.4-25.9)$ & $1.62(1.18-2.22)$ & & $1.25(0.80-1.93)$ & \\
\hline Waist circumference & & & & $<0.001$ & & $<0.001$ \\
\hline Normal & $387(20.2)$ & $11.1(08.3-14.7)$ & 1.00 & & 1.00 & \\
\hline Increased & $1,241(79.8)$ & $25.7(23.3-28.2)$ & $2.76(1.97-3.90)$ & & $3.31(2.05-5.34)$ & \\
\hline Hypertension & & & & $<0.001$ & & $<0.001$ \\
\hline No & $697(40.9)$ & $11.9(09.7-14.5)$ & 1.00 & & 1.00 & \\
\hline Yes & $1,005(59.1)$ & $29.1(26.3-31.9)$ & $3.02(2.32-3.96)$ & & $2.38(1.68-3.36)$ & \\
\hline Stroke & & & & 0.003 & & 0.356 \\
\hline No & $1,550(91.2)$ & $21.0(19.1-23.1)$ & 1.00 & & 1.00 & \\
\hline Yes & $151(8.8)$ & $31.8(24.8-39.7)$ & $1.75(1.22-2.52)$ & & $1.28(0.75-2.18)$ & \\
\hline Cardiovascular Disease & & & & $<0.001$ & & 0.061 \\
\hline No & $1,224(71.9)$ & $19.4(17.2-21.7)$ & 1.00 & & 1.00 & \\
\hline Yes & $478(28.1)$ & $28.9(25.0-33.1)$ & $1.70(1.33-2.16)$ & & $1.34(0.97-1.84)$ & \\
\hline Chronic kidney failure & & & & $<0.001$ & & 0.997 \\
\hline No & $1,624(95.4)$ & $21.2(19.2-23.2)$ & 1.00 & & 1.00 & \\
\hline Yes & $77(4.6)$ & $39.0(28.7-50.3)$ & $2.36(1.48-3.83)$ & & $0.99(0.45-2.22)$ & \\
\hline Depression & & & & $<0.001$ & & 0.186 \\
\hline No & $1,274(74.8)$ & $19.7(17.6-22.0)$ & 1.00 & & 1.00 & \\
\hline Yes & $427(25.2)$ & $29.0(24.9-33.5)$ & $1.67(1.30-2.14)$ & & $1.25(0.89-1.74)$ & \\
\hline
\end{tabular}

the increased life expectancy, and lifestyle characterized mainly by time spent sitting, and intake of foods rich in sugars and fats ${ }^{29-31}$.
In Brazil, the Ministry of Health has promoted strategies for the care and monitoring of diabetes for the population through assistance 
Table 2. Association of the incidence of diabetes in the elderly. Florianópolis, Brazil, 2009/10 and 2013/14.

\begin{tabular}{|c|c|c|c|c|c|c|}
\hline Variables & $\mathbf{n}^{\star}(\%)$ & $\begin{array}{c}\text { Incidence of } \\
\text { diabetes } \\
\text { (CI 95\%) }\end{array}$ & $\begin{array}{l}\text { OR Crude } \\
\text { (CI 95\%) }\end{array}$ & $\begin{array}{c}\mathrm{p} \\
\text { value }\end{array}$ & $\begin{array}{l}\text { OR adjusted } \\
\text { (CI 95\%) }\end{array}$ & $\begin{array}{c}\mathrm{p} \\
\text { value }\end{array}$ \\
\hline Gender & & & & 0.075 & & 0.204 \\
\hline Male & $319(37.2)$ & $6.1(4.1-9.3)$ & 1.00 & & 1.00 & \\
\hline Female & $540(62.8)$ & $9.6(7.5-12.2)$ & $1.61(0.96-2.70)$ & & $1.44(0.82-2.52)$ & \\
\hline Age Group (years) & & & & 0.167 & & 0.054 \\
\hline $60-69$ & $472(55.9)$ & $9.3(7.0-12.1)$ & 1.00 & & 1.00 & \\
\hline $70-79$ & $297(34.8)$ & $7.5(5.1-10.9)$ & $0.80(0.48-1.33)$ & & $0.71(0.42-1.23)$ & \\
\hline$\geq 80$ & $88(9.3)$ & $5.4(2.3-12.3)$ & $0.56(0.21-1.44)$ & & $0.45(1.70-1.23)$ & \\
\hline Marital status & & & & 0.186 & & 0.362 \\
\hline Married & $523(60.9)$ & $7.1(5.3-9.6)$ & 1.00 & & 1.00 & \\
\hline Single & $56(6.5)$ & $9.7(4.4-20.1)$ & $1.40(0.57-3.50)$ & & $1.22(0.49-3.08)$ & \\
\hline Divorced/separated & $59(6.8)$ & $14.5(8.0-25.0)$ & $2.22(1.06-4.66)$ & & $1.86(0.85-4.08)$ & \\
\hline Widow & $221(25.8)$ & $9.0(6.0-13.4)$ & $1.30(0.76-2.24)$ & & $1.22(0.67-2.25)$ & \\
\hline Schooling (years) & & & & 0.081 & & 0.077 \\
\hline$\geq 12$ & $232(27.1)$ & $6.0(3.7-9.9)$ & 1.00 & & 1.00 & \\
\hline $9-11$ & $134(15.6)$ & $7.6(4.3-13.2)$ & $1.27(0.57-2.85)$ & & $1.27(0.56-2.87)$ & \\
\hline $5-8$ & $135(15.8)$ & $9.4(6.4-12.7)$ & $1.61(0.75-3.43)$ & & $1.66(0.77-3.57)$ & \\
\hline $1-4$ & $302(34.9)$ & $9.0(6.4-12.7)$ & $1.54(0.81-2.92)$ & & $1.54(0.79-2.98)$ & \\
\hline No formal schooling & $56(6.6)$ & $12.5(6.4-2.32)$ & $2.12(0.89-5.47)$ & & $2.58(1.01-6.54)$ & \\
\hline $\begin{array}{l}\text { Physical activity of leisure } \\
\text { time }\end{array}$ & & & & 0.153 & & 0.192 \\
\hline Active & $277(32.2)$ & $6.4(4.1-9.9)$ & 1.00 & & 1.00 & \\
\hline Insufficiently active & $582(67.8)$ & $9.2(7.2-11.7)$ & $1.48(0.87-2.58)$ & & $1.45(0.83-2.52)$ & \\
\hline $\begin{array}{l}\text { Exchange messages } \\
\text { over the internet }\end{array}$ & & & & 0.294 & & 0.900 \\
\hline Yes & $211(24.5)$ & $6.7(4.1-10.8)$ & 1.00 & & 1.00 & \\
\hline No & $648(75.5)$ & $8.9(7.0-11.2)$ & $1.37(0.76-2.45)$ & & $1.04(0.51-2.13)$ & \\
\hline Waist circumference & & & & 0.007 & & 0.028 \\
\hline Normal & $235(28.2)$ & $4.1(2.2-7.5)$ & 1.00 & & 1.00 & \\
\hline Increased & $599(71.8)$ & $9.8(7.8-12.3)$ & $2.55(1.29-5.05)$ & & $2.23(1.09-4.57)$ & \\
\hline Hypertension & & & & 0.076 & & 0.493 \\
\hline No & $410(47.8)$ & $6.6(4.6-9.4)$ & 1.00 & & 1.00 & \\
\hline Yes & $449(52.2)$ & $9.9(7.5-12.8)$ & $1.54(0.96-2.49)$ & & $1.20(0.71-2.05)$ & \\
\hline Stroke & & & & 0.166 & & 0.149 \\
\hline No & $806(92.0)$ & $8.0(6.4-10.0)$ & 1.00 & & 1.00 & \\
\hline Yes & $53(86.9)$ & $13.1(6.7-24.2)$ & $1.74(0.80-3.80)$ & & $1.82(0.78-4.21)$ & \\
\hline Cardiovascular disease & & & & 0.059 & & 0.090 \\
\hline No & $646(75.2)$ & $7.3(5.6-9.5)$ & 1.00 & & 1.00 & \\
\hline Yes & $213(24.8)$ & $11.3(7.8-15.9)$ & $1.60(0.98-2.63)$ & & $1.58(0.92-2.70)$ & \\
\hline Chronic kidney failure & & & & 0.285 & & 0.647 \\
\hline No & $834(97.1)$ & $8.1(6.6-10.1)$ & 1.00 & & 1.00 & \\
\hline Yes & $25(2.9)$ & $14.0(5.2-31.9)$ & $1.81(0.61-5.32)$ & & $1.31(0.40-4.23)$ & \\
\hline Depression & & & & 0.021 & & 0.219 \\
\hline No & $663(77.2)$ & $7.2(5.5-9.3)$ & 1.00 & & 1.00 & \\
\hline Yes & $196(22.8)$ & $12.1(8.4-17.1)$ & $1.79(1.10-2.93)$ & & $1.40(0.81-2.41)$ & \\
\hline
\end{tabular}

${ }^{*}$ Sample without diabetes at baseline 95\% IC: Confidence Interval 95\%; OR: odds ratio; Boldface indicates statistical significance $(\mathrm{p}<0.05)^{*}$.

path, identification of people with diabetes and/ or risk factors, as well as the definition of goals and indicators from this perspective of Health
Primary Care ${ }^{32}$. This fact may contribute to the faster diagnosis and consequently, increasing the percentage of the disease over time. 
In this study, the incidence and factors associated to diabetes were similar to those of the $\mathrm{Ca}$ nadian Study of Health and Aging cohort (8.6\%) during the 4.5-year following-up period ${ }^{33}$ and Health, Wellness and Aging Study (SABE) study $(7.7 \%)^{20}$. The implication of the results found was that over the years, the elderly presented a greater predisposition to health problems, which may be followed by a lower condition for coping, and repercussions on their self-care ${ }^{6-9}$.

Important association of diabetes with low educational level was found in present study. In China, elderly and adults with lower educational levels had a higher prevalence of diabetes ${ }^{18}$, consistent to the results found in the southeastern region of Brazil which the elderly with the highest level of schooling had a lower prevalence of diabetes ${ }^{17}$.

Although not found in this study, incidence data from the United Kingdom ${ }^{11}$ and from Chi$\mathrm{na}^{34}$ showed that low educational level was associated to the risk of diabetes, especially among the elderly aged $65-74^{11}$. It seems that higher schooling can be considered a protection factor, therefore it provides the expansion of self-care resources in relation to their health and the disease itself ${ }^{35}$.

The elderly have a higher risk for the development of the disease, mainly type $2^{36}$.This fact is due to the combined effects of increased insulin resistance and the function of pancreatic islets impaired with aging ${ }^{37}$.

Increased waist circumference was associated to diabetes in this study in both prevalence and incidence. The fat located in the central region has been identified as an important risk factor for several chronic diseases, including diabetes, cardiovascular diseases, dyslipidemias, metabolic syndrome and some types of cancer ${ }^{38}$.

In the longitudinal study by Almeida ${ }^{20}$, more than $50 \%$ of the elderly had high waist circumference measurements, and the highest proportion was associated with those who reported diabetes. Conversely to this result, Chhtri and Chapman ${ }^{39}$ found that reducing waist circumference, and body weight, and routinely including physical activity helped to prevent the disease.

The prevalence of hypertension affects approximately twice as many people with diabetes as those who do not have the disease ${ }^{13}$. According to Francisco et al. ${ }^{14}$, hypertension is associated with a greater degree of insulin resistance, and antihypertensive drugs may aggravate this condition, and make people more likely to develop diabetes.
American Diabetes Association warns that people affected with diabetes are at increased risk for hypertension, a result also found in the present study. Therefore, they should adopt an active and healthy lifestyle, with reduction in sodium consumption and the inclusion of physical activity practice ${ }^{40}$.

Seeking to reduce or even eliminate barriers to self-care with chronic non-communicable diseases, the International Diabetes Federation recommends that health education strategies must be considered as an integral part of diabetes care, with interactively involvement of the person with the Educator ${ }^{41}$.

The Brazilian public health policies have been fostered through health promotion actions with emphasis on the autonomy and empowerment of the population. These actions have been implemented in the Unified Health System by means of conversation wheels, individual and/or collective consultations ${ }^{42}$, which also reach those already affected by diabetes ${ }^{5}$.

The self-reported measure may be a limitation to allow it to identify known cases, the participant's information consent and it remembrance of disease ${ }^{43}$. In addition, different studies show moderate sensitivity and high specificity of the self-reported diabetes measure when compared to clinical exams $s^{6,14,44-46}$, indicating a real underestimation of the cases in the population of the present study.

This study outstands the usage of a representative sample of the municipality in the baseline and in the following-up, allowing the extrapolation of the results to the general population. Besides a high response rate in the baseline and in the second wave, contributed to the internal validity, decreasing the chance of systematic errors occurrences, with reproducibility varying from 0.5 to 0.9 (kappa values) independently in both study waves.

\section{Conclusions}

The results showed that the elderly without formal schooling or with low educational levels, those with increased waist circumference, and those with hypertension, were more likely to report diabetes in 2009/10. After four years of following-up, those who had increased waist circumference on the baseline increased their odds ratio of developing diabetes.

Considering the scenario found, it is suggested that behavior change programs, educational 
and social campaigns be encouraged/reinforced by the health institutions in Florianopolis, mainly because the disease is underdiagnosed and reach specific subgroups within the elderly population of the municipality.

\section{Collaborations}

CES Santos participated in the conception and design of the study, analysis and interpretation of the results, drafting of the manuscript and critical review of the content of the article. CR Rech, IJC Schneider, DL Antes e E d'Orsi participated in the writing of the manuscript and critical review of the content of the article. E d'Orsi administered the EpiFloripa Idoso Project. TRB Benedetti guided the study, participated in the analysis and interpretation of the data, drafting of the manuscript and critical review of the content.

\section{Acknowledgements}

To the technicians of the Brazilian Institute of Geography and Statistics (IBGE) and the Municipal Health Department of Florianopolis for the assistance in the operationalization of the EpiFloripa Ageing Study 2009/2010. To the National Council of Scientific and Technological Development, the Coordination of Improvement of Higher Education Personnel and the Federal University of Santa Catarina. 


\section{References}

1. World Health Organization (WHO). Global action plan for the prevention and control of noncommunicable diseases 2013-2020. Geneva: WHO; 2013.

2. Federacion International de Diabetes (FID). Diabetes. Versión en línea del Atlas de la Diabetes de la FID. Bruxelas: FID; 2015.

3. World Health Organization (WHO). Diabetes 2008. Geneva: WHO; 2008.

4. Brasil. Ministério da Saúde (MS). Vigilância de fatores de risco e proteção para doenças crônicas por inquérito telefônico. Brasilia: MS; 2015.

5. Sociedade Brasileira de Diabetes (SBD). Diabetes na prática clínica. Rio de Janeiro: SBD; 2015.

6. Mendes TAB, Goldbaum M, Barros MBA, Cesar CLG, Carandina L, Alves MCGP. Diabetes mellitus: fatores associados à prevalência em idosos, medidas e práticas de controle e uso dos serviços de saúde em São Paulo, Brasil. Cad Saude Publica 2011; 27(6):1233-1243.

7. Mulnier HE, Seaman HE, Raleigh VS, SoedamahMuthu SS, Colhoun HM, Lawrenson RA. Mortality in people with type 2 diabetes in the UK. Diabet Med 2006; 23(5):516-521.

8. Bahia LR, Araujo DV, Schaan BD, Dib SA, Negrato CA, Leao MP, Ramos AJS, Forti AC, Gomes MB, Foss MC, Monteiro RA, Sartorelli D, Franco LJ. The costs of type 2 diabetes mellitus outpatient care in the Brazilian public health system. Value in health 2011; 14(5 Supl. 1):S137-140.

9. Schmidt MI, Duncan BB, Azevedo e Silva G, Menezes AM, Monteiro CA, Barreto SM, Chor D, Menezes PR. Chronic non-communicable diseases in Brazil: burden and current challenges. Lancet 2011; 377(9781):1949-1461.

10. Hemminki K, Li X, Sundquist K, Sundquist J. Familial risks for type 2 diabetes in Sweden. Diabetes Care 2010; 33(2):293-297.

11. Tanaka T, Gjonca E, Gulliford MC. Income, wealth and risk of diabetes among older adults: cohort study using the English longitudinal study of ageing. Eur J Public Health 2011; 22(3):310-317.

12. Andrade F. Estimating diabetes and diabetes-free life expectancy in Mexico and seven major cities in Latin America and the Caribbean. Rev Panam Salud Publica 2009; 26(1):9-16.

13. Freitas LRS, Garcia LP. Evolução da prevalência do diabetes e deste associado à hipertensão arterial no Brasil: análise da Pesquisa Nacional por Amostra de Domicílios, 1998, 2003 e 2008. Epidemiol. Serv. Saúde. 2012; 27(1):7-19.

14. Francisco PMSB, Belon AP, Barros MBA, Carandina L, Alves MCGP, Goldbaum M, Cesar CLG. Diabetes auto-referido em idosos: prevalência, fatores associados e práticas de controle. Cad Saude Publica 2010; 26(1):175-185.
15. Sartorelli DS, Franco LJ, Cardoso MA. Intervenção nutricional e prevenção primária do diabetes mellitus tipo 2: uma revisão sistemática. Cad Saude Publica 2006; 22(1):7-18.

16. Nemesure B, Wu SY, Hennis A, Leske MC, Group BESS. The relationship of body mass index and waisthip ratio on the 9-year incidence of diabetes and hypertension in a predominantly African-origin population. Ann Epidemiol. 2008; 18(8):657-663.

17. Barros MBA, Francisco PMSB, LimaMG, Cesar CLG. Social inequalities in health among the elderly. Cad Saude Publica 2011; 27(2):198-208.

18. Qin Y, Wang R, Ma X, Zhao Y, Lu J, Wu C, He J. Prevalence, Awareness, Treatment and Control of Diabetes Mellitus-A Population Based Study in Shanghai, China. Int J Environ Res Public Health 2016; 13(5):2-11.

19. Jefferis BJ, Whincup PH, Lennon L, Wannamethee SG. Longitudinal associations between changes in physical activity and onset of type 2 diabetes in older British men: the influence of adiposity. Diabetes care 2012; 35(9):1876-1883.

20. Almeida MFD. Diabetes Mellitus Referida: incidência e preditores em coorte de idosos domiciliados no município de São Paulo: Estudo SABE-Saúde, Bem-Estar e Envelhecimento [dissertação]. São Paulo: Faculdade de São Paulo; 2010.

21. Programa das Nações Unidas para o Desenvolvimento (PNUD). Atlas de desenvolvimento Humano no Brasil. Brasília: PNUD; 2013.

22. Benedetti TR, Mazo GZ, Barros MV. Aplicação do Questionário Internacional de Atividades Físicas para avaliação do nível de atividades físicas de mulheres idosas: validade concorrente e reprodutibilidade teste-reteste. Rev. bras. ciênc. mov, 2004; 12(1):25-34.

23. World Health Organization (WHO). Obesity: preventing and managing the global epidemic. Report of a WHO consultation. Geneva: WHO; 2000.

24. Lebrão ML, Duarte YAO, Santos JLF, Laurenti R. Evolução nas condições de vida e saúde da população idosa do Município de São Paulo. Sao Paulo Perspec 2008; 22(2):30-45.

25. Stopa SR, César CLG, Segri NJ, Goldbaum M, Guimarães VMV, Alves MCGP, Barros MBA. Self-reported diabetes in older people: comparison of prevalences and control measures. Rev Saude Publica 2014; 48(4):554-562.

26. Dankner R, Geulayov G, Olmer L, Kaplan G. Undetected type 2 diabetes in older adults. Age Ageing 2009; 38(1):56-62.

27. Tanjania PT, Moradinazar M, Mottlagh ME, Najafib F. The prevalence of diabetes mellitus (DM) type II among Iranian elderly population and its association with other age-related diseases, 2012. Arch Gerontol Geriatr 2015; 60(3):373-379. 
28. Pelegrini A, Coqueiro RS, Petroski EL, Benedetti TRB. Self-reported diabetes mellitus and its association with overweight in older adults. Rev. Bras. Cineantropom. Desempenho Hum 2011; 13(6):442-447.

29. Shaw JE, Sicree RA, Zimmet PZ. Global estimates of the prevalence of diabetes for 2010 and 2030. Diabetes Res Clin Pract 2010; 87(1):4-14.

30. World Health Organization (WHO). Global status report on noncommunicable diseases 2010. Geneva: WHO; 2011.

31. Danaei G, Finucane MM, Lu Y, Singh GM, Cowan MJ, Paciorek CJ, Lin JK, Farzadfar F, Khang YH, Stevens GA, Rao M, Ali MK, Riley LM, Robinson CA, Ezzati M, Global Burden of Metabolic Risk Factors of Chronic Diseases Collaborating Group (Blood Glucose). National, regional, and global trends in fasting plasma glucose and diabetes prevalence since 1980: systematic analysis of health examination surveys and epidemiological studies with 370 country-years and 2.7 million participants. Lancet 2011; 378(9785):31-40.

32. Brasil. Ministério da Saúde (MS). Estratégias para o cuidado da pessoa com doença crônica: diabetes mellitus. Brasília: MS; 2013.

33. Rockwood K, Awalt E, MacKnight C, McDowell I. Incidence and outcomes of diabetes mellitus in elderly people: report from the Canadian Study of Health and Aging. CMAJ 2000; 162(6):769-772.

34. Shi L, Shu XO, Li H, Cai H, Liu Q, Zheng W, Xiang YB, Villegas R. Physical activity, smoking, and alcohol consumption in association with incidence of type 2 diabetes among middle-aged and elderly Chinese men. PloS One 2013; 8(11):77919.

35. Rodrigues FFL, Santos MA, Teixeira CRS, Gonela JT, Zanett ML. Relação entre conhecimento, atitude, escolaridade e tempo de doença em indivíduos com diabetes mellitus. Acta Paul Enferm 2012; 25(2):284-290.

36. Tracey ML, McHugh SM, Fitzgerald AP, Buckley CM, Canavan RJ, Kearney PM. Risk Factors for Macro- and Microvascular Complications among Older Adults with Diagnosed Type 2 Diabetes: Findings from The Irish Longitudinal Study on Ageing. J Diabetes Res 2016; 2016:5975903.

37. Kirkman MS, Briscoe VJ, Clark N, Florez H, Haas LB, Halter JB, Huang ES, Korytkowski MT, Munshi MN, Odegard PS, Pratley RE, Swift CS; Consensus Development Conference on Diabetes and Older Adults. Diabetes in older adults: a consensus report. J Am Geriatr Soc 2012; 60(12):2342-2356

38. Centers for Disease Control and Prevention (CDCP). Diabetes Public Health Resource. Atlanta: CDCP; 2012.

39. Chhetri MR, Chapman RS. Prevalence and determinants of diabetes among the elderly population in the Kathmandu Valley of Nepal. Nepal Med Coll J 2009; 11(1):34-38.
40. Standards of Medical Care in Diabetes. Diabetes Care 2012; 35(35).

41. Federacion International de Diabetes (FID). The Diabetes Education Modules. Bruxelas: FID; 2011.

42. Brasil. Ministério da Saúde (MS). Curso de Aperfeiçoamento em Implementação da Política de Promoção da Saúde: Programa Academia da Saúde. Brasilia: MS; 2015.

43. Goldman N, Lin IF, Weinstein M, Lin YH. Evaluating the quality of self-reports of hypertension and diabetes. J Clin Epidemiol 2003; 56(2):148-154.

44. Ding D, Chong S, Jalaludin B, Comino E, Bauman AE Risk factors of incident type 2-diabetes mellitus over a 3-year follow-up: Results from a large Australian sample. Diabetes Res Clin Pract 2015; 108(2):306-315.

45. Comino EJ, Haas M, Flack J, Jalaludin B, Jorm L, Harris MF. Validating self-report of diabetes use by participants in the 45 and up study: a record linkage study. BMC Health Serv Res 2013; 13:1-9.

46. Menezes TN, Oliveira ECT. Validade e concordância do diabetes mellitus referido em idosos. Cien Saude Colet 2019; 24(1):27-34.

Artigo apresentado em 14/08/2017

Aprovado em 17/04/2018

Versão final apresentada em 19/04/2018 
